\title{
Multiple Crossings of a Large Glacial River by Canada Lynx (Lynx canadensis)
}

\author{
DASHIELl FeIERABEND ${ }^{1,3}$ and KNUT KIELland ${ }^{1,2}$ \\ ${ }^{1}$ Department of Biology and Wildlife, University of Alaska Fairbanks, Fairbanks, Alaska 99775 USA \\ ${ }^{2}$ Institute of Arctic Biology, University of Alaska Fairbanks, Fairbanks, Alaska 99775 USA \\ ${ }^{3}$ Corresponding author: dfeierab@alaska.edu
}

Feierabend, Dashiell, and Knut Kielland. 2014. Multiple crossings of a large glacial river by Canada Lynx (Lynx canadensis). Canadian Field-Naturalist 128(1): 80-83.

Rivers may act as barriers to the movement of terrestrial mammals, which could limit dispersal and gene flow. Glacial rivers are particularly hazardous because of the cold water temperature and swift current. Yet, we determined that 2 Canada Lynx (Lynx canadensis) equipped with GPS collars repeatedly swam across the main channel of the Tanana River in interior Alaska in 2011 as late in the season as November, when the average minimum daily air temperature was $-27^{\circ} \mathrm{C}$. These observations are consistent with the low level of genetic structure observed in Canada Lynx in northwestern North America and suggest that even large rivers may pose less of a barrier to movement by Canada Lynx than expected.

Key Words: barrier; boreal forests; Canada Lynx; Lynx canadensis; dispersal; home range; river; Alaska

\section{Introduction}

Rivers may act as barriers to the movement of terrestrial mammals because of the risk of injury or death from drowning (Storm et al. 1976; Peres et al. 1996; Garroway et al. 2011). By limiting dispersal into potentially favorable habitats as well as constraining gene flow, such barriers may have both ecological and genetic consequences (Puth and Wilson 2001). In northern regions, the near-freezing temperatures of glacial rivers add to the dangers posed by swift currents and floating debris.

Whereas large ungulates such as Moose (Alces americanus) and Caribou (Rangifer tarandus) regularly cross open glacial rivers during seasonal migrations (Griffith et al. 2002; Kellie 2005), these rivers presumably pose considerably more danger to medium-sized mammals, such as Coyotes (Canis latrans) and Canada Lynx (Lynx canadensis).

The only published report of a Canada Lynx crossing an open river describes an individual that swam across a $3.2 \mathrm{~km}$ wide section of the Yukon River (Kobalenko 1997). There are several unpublished reports of Canada Lynx crossing open rivers in Alaska and Canada, but the frequency with which individual Canada Lynx make such crossings is unknown. Here, we report the behavior of 2 Canada Lynx that repeatedly crossed the glacially fed Tanana River in interior Alaska during fall and early winter, before the river was sufficiently frozen to allow them to cross on foot.

\section{Methods \\ Study area}

This study took place in the Bonanza Creek LongTerm Ecological Research (LTER) site $\left(65^{\circ},-148^{\circ}\right)$ and surrounding areas, approximately $20 \mathrm{~km}$ southwest of Fairbanks, Alaska, U.S.A. Upland, lowland, and floodplain boreal habitats in the study area included
Black Spruce (Picea mariana), White Spruce (Picea glauca), Balsam Poplar (Populus balsamifera), mixed White Spruce-Alaska Paper Birch (Betula neoalaskana), Trembling Aspen (Populus tremuloides), and regenerating stands of Alaska Paper Birch, Trembling Aspen, and shrub birch (Betula spp.) in areas that had burned in the previous 30 years.

The Tanana River, which is the largest tributary of the Yukon River, flows across the southern edge of the site and is highly braided. The Tanana River has an average discharge volume of $1600 \mathrm{~m}^{3} \cdot \mathrm{s}^{-1}$ with a low of approximately $560 \mathrm{~m}^{3} \cdot \mathrm{s}^{-1}$ in spring and fall prior to freeze-up, but it can reach a maximum of about $2300 \mathrm{~m}^{3} \cdot \mathrm{s}^{-1}$ during floods in late summer (USGS 2013*).

The river is typically frozen from late November until April-May (KK, personal observation). Openwater temperatures in late fall/early winter are just above freezing (KK, unpublished data). Average maximum and minimum air temperatures in the study area were $15^{\circ} \mathrm{C}$ and $4^{\circ} \mathrm{C}$, respectively, in September 2011, $3^{\circ} \mathrm{C}$ and $-6^{\circ} \mathrm{C}$, respectively, in October 2011 , and $-18^{\circ} \mathrm{C}$ and $-27^{\circ} \mathrm{C}$, respectively, in November 2011 (Bonanza Creek LTER 2013*).

\section{Canada Lynx capture and collaring}

Between June 2008 and November 2012, we used padded Soft-catch ${ }^{\circledR}$ traps (No. 3, Woodstream Corp., Lititz, Penn.), Belisle foot snares (Wildlife Control Supplies, East Granby, Conn.), and home-made cage traps to live-capture 23 Canada Lynx. Scent lures and animal carcasses were used to bait traps. We administered Telazol ( $3 \mathrm{mg} / \mathrm{kg})$ to trapped individuals using a jab stick, then determined sex and weight, and we fitted 12 individuals with timed-release collars equipped with global positioning system (GPS) loggers, VHF transmitters, and activity sensors (model G2110B, Advanced Telemetry Systems, Isanti, Minn). Collars 
weighed $350 \mathrm{~g}$ (approximately $2-4 \%$ of the mass of Canada Lynx in Alaska) (Alaska Department of Fish and Game 2008*) and were not expected to affect survival (Sikes et al. 2011). The activity sensor provided a count of the number of changes in the position of a tilt switch on the collar and represented a unitless measure of an animal's activity. Collars were programmed to record locations at 5-hour intervals.

Capture and handling procedures followed animal care and use guidelines of the American Society of Mammalogists (Sikes et al. 2011) and were approved by the University of Alaska Fairbanks Institutional Animal Care and Use Committee (Protocol 135202-3) and the Alaska Department of Fish and Game (Permit 11-041).

\section{Analysis}

We report movements for 2 adult Canada Lynx: a male collared from 2 September to 5 November 2011 and a female collared from 15 August to 21 November 2011. We recovered the male's collar after it prematurely released from the animal, and we recovered the female's collar after the animal was trapped by a professional fur trapper. We counted the number of times each Canada Lynx crossed the main channel of the Tanana River as well as major braids and sloughs, based on $0.6-\mathrm{m}$ resolution DOQQ imagery (USDA 2007*) in ArcGIS 10.0 (ESRI, Redlands, Calif.). Crossings were identified by consecutive GPS locations situated on opposite sides of the river. Because Canada Lynx could conceivably have entered and exited the river from the same bank, this count represents the minimum number of times each Canada Lynx was in the river during the sampling period.

We estimated home range sizes using Brownian bridge movement models (Horne et al. 2007). Success rates for scheduled GPS fixes were $49 \%$ and $61 \%$ for the male and female Canada Lynx, respectively. GPS accuracy varied, depending on the orientation of the GPS antenna to the sky and the number and configuration of satellites available.

We estimated location accuracy using two stationary collars programmed to collect fixes at 5-hour intervals in the field under dense vegetative cover and open sky for 60 hours. Using the Standard Distance tool in ArcGIS, we found the standard deviations from the mean centers of GPS locations to be $6.7 \mathrm{~m}(n=12)$ and $3.1 \mathrm{~m}(n=12)$ under cover and open sky, respectively. When calculating Canada Lynx home ranges, we used a conservative estimated location error of 30 $\mathrm{m}$ based on data from Horne et al. (2007).

We used all GPS location fixes (146 for the male and 287 for the female) over all days fixes were obtained (64 days for the male and 98 days for the female). We calculated utilization distributions using the kernelbb function (adehabitat package) in R (R Core Team 2013*) and extracted isopleths using Geospatial Modeling Environment (Beyer 2012*).
Home range boundaries were defined by $90 \%$ isopleths (Börger et al. 2006), and core use areas were defined by isopleths $($ male $=37 \%$; female $=33 \%$ ) that divided intensively used areas from peripheral areas of less intense use. This was done by fitting an exponential regression to a plot of utilization distribution (UD) area against utilization distribution volume (i.e., isopleth value) and identifying the utilization distribution volume for which the slope of the regression line was equal to 1 (Vander Wal and Rodgers 2012).

We quantified diel activity patterns using average collar activity counts and movement rates derived from distances between consecutive GPS locations. In order to avoid biased movement rates over longer intervals, we used only GPS locations that were 5 hours apart. Because activity accrued and movements occurred over 5 -hour periods, we calculated activity and movement for a given time of day as the average of all 5-hour periods containing that time (e.g., activity at 1300 was calculated as an average of activity counts that spanned the time periods $0900-1359,1000-1459,1100-1559$, 1200-1659, and 1300-1759).

\section{Results}

We collected location data from a total of 12 Canada Lynx equipped with GPS collars between December 2009 and January 2013. Of the 10 animals whose data spanned at least one month, 2 Canada Lynx made crossings of the Tanana River when it was frozen in April, 1 male crossed the main channel twice in two days when the river was still open in October, another male crossed the main channel 6 times in November, when the river was likely only partially frozen, and a male and a female repeatedly crossed the unfrozen river between September and November. Only the home ranges of the latter 2 individuals spanned the river.

Of those 2 Canada Lynx, the male made 14 crossings of the main channel of the Tanana River between 4 September and 4 November 2011, and he swam across smaller river braids and sloughs $(15-50 \mathrm{~m}$ in width) an additional 20 times (Figure 1). The female made 11 crossings of the main river channel between 13 September and 21 November, and she swam across smaller river braids and sloughs an additional 40 times (Figure 1).

We could not determine the exact time of day of most crossings. However, both Canada Lynx crossed river channels multiple times in a given 24-hour period and each animal crossed the main channel at least 3 times at night. The male exhibited a more diurnal pattern of activity than the female (Figure 2). Home ranges were $201 \mathrm{~km}^{2}$ and $254 \mathrm{~km}^{2}$ for the male and female, respectively. River water constituted $6 \%$ of each home range, and river water constituted $12 \%$ and $18 \%$ of core use areas for the male and the female, respectively. Both of the Canada Lynx made considerable use of islands in the river $(28 \%$ of locations for the male and $52 \%$ of locations for the female). 


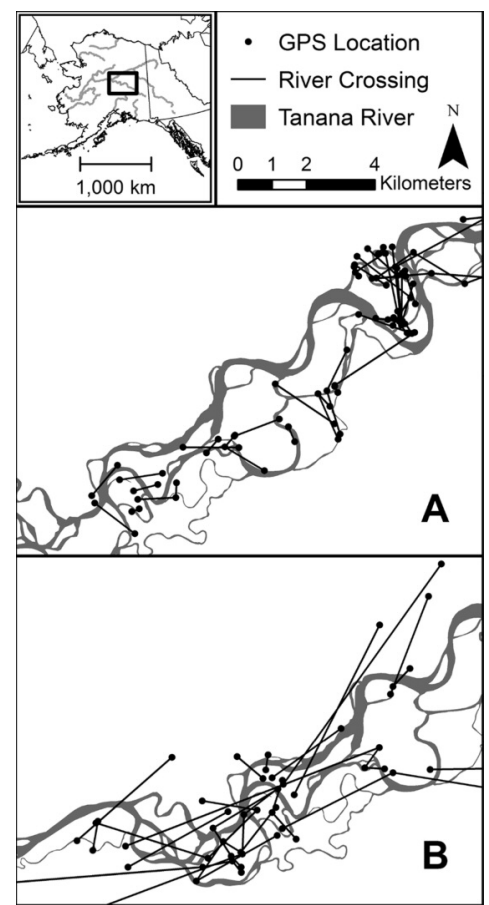

FIGURE 1. Movement across the Tanana River near Fairbanks, Alaska $\left(65^{\circ},-148^{\circ}\right)$, by (A) a female Canada Lynx (Lynx canadensis) equipped with a GPS collar between 15 August and 21 November 2011 and (B) a male Canada Lynx equipped with a GPS collar between 2 September and 5 November 2011. Lines connect consecutive GPS locations for Canada Lynx on either side of the river but do not indicate the actual routes travelled.

\section{Discussion}

We documented the regular crossing of a large, swift glacial river by 2 Canada Lynx during times of the year when cold air temperatures and initial ice formation elevated the dangers of such behavior. Due to the length of time between GPS locations, we could not determine the exact entry and exit points of the Canada Lynx on the river, but we can be reasonably sure that both Canada Lynx spent considerable time traversing sections of flowing water that were $100-300 \mathrm{~m}$ in width.

Assuming an estimated maximum swimming rate of $50 \mathrm{~m} \cdot \mathrm{min}^{-1}$ (the maximum sprinting speed of a human swimmer is $120 \mathrm{~m} \cdot \mathrm{min}^{-1}$ ) (Toussaint and Trultens 2005) and an actual travel distance twice the width of the river channel (to allow for the current, which was 1-2 $\mathrm{m} \cdot \mathrm{s}^{-1}$ ) (Johnson et al. 2010*), we estimate that it would have taken a Canada Lynx 4-12 minutes to cross the main stem of the Tanana River, depending on channel configuration. Moreover, in October and November, shelf ice along the banks of the river could have made exiting the water difficult. Sub-freezing air

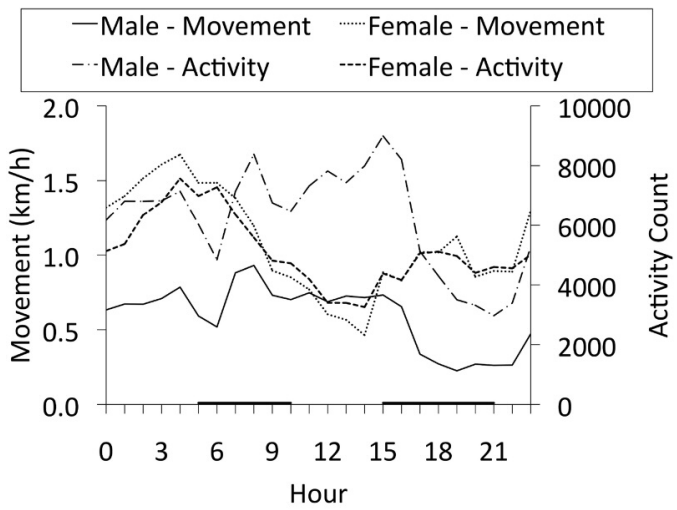

FIGURE 2. Diel activity and movement patterns of a male Canada Lynx (Lynx canadensis) equipped with a GPS collar between 2 September and 5 November 2011 and a female Canada Lynx equipped with a GPS collar between 15 August and 21 November 2011 near Fairbanks, Alaska. Activity is quantified as the number of changes in the position of a tilt switch on the collar. Black lines along the $\mathrm{x}$-axis indicate periods of sunrise and sunset.

temperatures surely caused the animals' fur to freeze, drastically reducing its insulative capacity, yet both Canada Lynx often crossed the river multiple times in a single day. We can only speculate as to why these individuals swam across the cold river.

The abundance of Snowshoe Hares (Lepus americanus) in the study area reached a cyclical peak in the fall of 2009 and had declined by nearly $50 \%$ by the fall of 2010 (Feierabend 2013). We do not have a direct measure of Canada Lynx abundance during this time, but Canada Lynx tracks remained common in the study area through the winter of 2010-2011 despite the declining numbers of "sealed" Canada Lynx pelts (pelts with an official marker or locking seal tag (seal) placed by the Alaska Department of Fish and Game) (all Canada Lynx taken in Alaska must be sealed) in interior Alaska following the winter of 2008-2009 (Alaska Department of Fish and Game 2012*). It may be that Canada Lynx were foraging over increasingly large areas as Snowshoe Hare populations declined. The islands used by the Canada Lynx in this study were up to $4 \mathrm{~km}^{2}$ in size and could have harbored populations of Snowshoe Hares, but most GPS locations were on much smaller islands that were more likely used as stepping stones during river crossings than for foraging.

Alternatively, the territoriality of neighboring Canada Lynx may have forced the 2 observed individuals to concentrate their movements along the margins of the river. However, given the apparent risks of crossing the Tanana River, one might expect a Canada Lynx simply to cross once in order to explore more suitable habitat in the expansive Tanana Flats to the south. In fact, both individuals did travel up to $30 \mathrm{~km}$ southeast of the 
river for as long as 12 days at a time before returning to their previous locations, where they again crossed the river.

These observations suggest that even hazardous rivers in freezing conditions may not represent significant barriers to highly mobile mesocarnivores such as Canada Lynx and that foraging movements as well as dispersal that include river crossings may take place under such conditions. This ability to traverse apparent physical barriers is consistent with observations of long-distance dispersal capacity in the Canada Lynx (Mowat et al. 2000) and the low level of genetic structure among Canada Lynx populations in northwestern North America (Rueness et al. 2003; Row et al. 2012).

\section{Acknowledgements}

This research was supported by the Bonanza Creek Long-Term Ecological Research program funded jointly by the National Science Foundation (DEB-1026415) and the U.S. Forest Service, U.S. Department of Agriculture (PNW01-JV11261952-231). We thank K. Olson for help in the field and K. Hundertmark, T. Jung, E. Koen, and M. O'Donoghue for critical comments on the manuscript.

\section{Documents Cited (marked * in text)}

Alaska Department of Fish and Game. 2008. Lynx: Wildlife Notebook Series. http://www.adfg.alaska.gov/static/edu cation/wns/lynx. (Accessed 16 January 2014).

Alaska Department of Fish and Game. 2012. Trapper Questionnaire. Statewide Annual Report: 1 July 2010-30 June 2011. http://www.adfg.alaska.gov/index.cfm?adfg= trapping.reports. (Accessed 1 June 2013).

Beyer, H. L. 2012. Geospatial Modeling Environment (Version 0.7.1.0). http://www.spatialecology.com/gme.

Bonanza Creek LTER. 2013. Bonanza Creek LTER Data. http://www.lter.uaf.edu/data.cfm. (Accessed 1 September 2013).

Johnson, J. B., P. Duvoy, K. Moerlein, A. E. Rosenberger, J. W. Schmid, A. E. Seitz, and H. A. Toniolo. 2010. Assessment of the Tanana River (Nenana, AK) for hydrokinetic turbine operations. http://www.akenergyauthority .org/OceanRiver/2010-2-16_ACEPLecture.pdf. (Accessed 21 September 2013).

R Core Team. 2013. R: A language and environment for statistical computing. R Foundation for Statistical Computing, Vienna, Austria. http://www.R-project.org.

USDA. 2007. Natural Resources Conservation Science Geospatial Gateway. http://datagateway.nrcs.usda.gov. (Accessed 25 July 2013).

USGS. 2013. Surface-Water Data for Alaska. http://water data.usgs.gov/ak/nwis/sw. (Accessed 22 September 2013).

\section{Literature Cited}

Börger, L., N. Franconi, G. De Michele, A. Gantz, F. Meschi, A. Manica, S. Lovari, and T. Coulson. 2006. Effects of sampling regime on the mean and variance of home range size estimates. Journal of Animal Ecology 75: 1393-1405.

Feierabend, D. S. 2013. Survival and activity patterns of snowshoe hares (Lepus americanus) in interior Alaska.
M.Sc. thesis, University of Alaska Fairbanks, Fairbanks, Alaska.

Garroway, C. J., J. Bowman, and P. J. Wilson. 2011. Using a genetic network to parameterize a landscape resistance surface for fishers, Martes pennanti. Molecular Ecology 20: $3978-3988$.

Griffith, B., D. C. Douglas, N. E. Walsh, D. D. Young, T. R. McCabe, D. E. Russell, R. G. White, R. D. Cameron, and K. R. Whitten. 2002. The Porcupine caribou herd. Pages 8-27 in Arctic Refuge Coastal Plain Terrestrial Wildlife Research Summaries. Edited by D. C. Douglas, P. E. Reynolds, and E. B. Rhode. Biological Science Report USGS/BRD/BSR-2002-0001. U.S. Geological Survey, Biological Resources Division, Reston, Virginia.

Horne, J. S., E. O. Garton, S. M. Krone, and J. S. Lewis. 2007. Analyzing animal movements using Brownian bridges. Ecology 88: 2354-2363.

Kellie, K. A. 2005. Summer movements of female moose at high density. M.Sc. thesis. University of Alaska Fairbanks, Fairbanks, Alaska.

Kobalenko, J. 1997. Forest cats of North America: cougars, bobcats, and lynx. Firefly Books, Willowdale, Ontario. 128 pages.

Mowat, G., K. G. Poole, and M. O'Donoghue. 2000. Ecology of lynx in northern Canada and Alaska. Pages 265-306 in Ecology and Conservation of Lynx in the United States. Edited by L. F. Ruggiero, K. B. Aubry, S. W. Buskirk, G. M. Koehler, C. J. Krebs, K. S. McKelvey, and J. R. Squires. General Technical Report RMRS-GTR-30WWW. U.S. Department of Agriculture, Forest Service, Rocky Mountain Research Station, Fort Collins, Colorado.

Peres, C. A., J. L. Patton, and M. N. da Silva. 1996. Riverine barriers and gene flow in Amazonian saddle-back tamarins. Folia Primatology (Basel) 67: 113-124.

Puth, L. M., and K. A. Wilson. 2001. Boundaries and corridors as a continuum of ecological flow control: lessons from rivers and streams. Conservation Biology 15: 21-30.

Row, J. R., C. Gomez, E. L. Koen, J. Bowman, D. L. Murray, and P. J. Wilson. 2012. Dispersal promotes high gene flow among Canada lynx populations across mainland North America. Conservation Genetics 13: 1259-1268.

Rueness, E. K., N. C. Stenseth, M. O'Donoghue, S. Boutin, H. Ellegren, and K. S. Jakobsen. 2003. Ecological and genetic spatial structuring in the Canadian lynx. Nature 425: 69-72.

Sikes, R. S., W. L. Gannon, and the Animal Care and Use Committee of the American Society of Mammalogists. 2011. Guidelines of the American Society of Mammalogists for the use of wild mammals in research. Journal of Mammalogy 92: 235-253.

Storm, G. L., R. D. Andrews, R. L. Phillips, R. A. Bishop, D. B. Siniff, and J. R. Tester. 1976. Morphology, reproduction, dispersal, and mortality of midwestern red fox populations. Wildlife Monographs 49. 82 pages.

Toussaint, H., and M. Trultens. 2005. Biomechanical aspects of peak performance in human swimming. Animal Biology 55: $17-40$.

Vander Wal, E., and A. R. Rodgers. 2012. An individualbased quantitative approach for delineating core areas of animal space use. Ecological Modelling 224: 48-53.

Received 24 October 2013

Accepted 15 November 2013 